

\section{Using Economics to Determine the Efficient Curtailment of Wind Energy}

\section{Erik Ela}

Prepared under Task No. WER9.5501

Technical Report NREL/TP-550-45071

February 2009

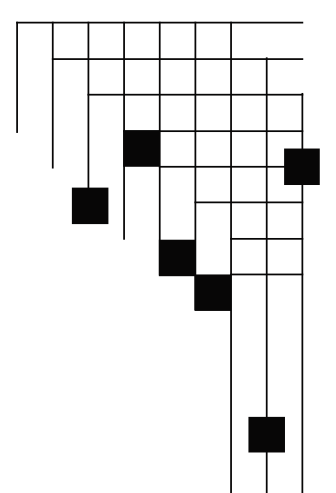

National Renewable Energy Laboratory 1617 Cole Boulevard, Golden, Colorado 80401-3393 303-275-3000 • www.nrel.gov

NREL is a national laboratory of the U.S. Department of Energy Office of Energy Efficiency and Renewable Energy

Operated by the Alliance for Sustainable Energy, LLC

Contract No. DE-AC36-08-G028308 


\section{NOTICE}

This report was prepared as an account of work sponsored by an agency of the United States government. Neither the United States government nor any agency thereof, nor any of their employees, makes any warranty, express or implied, or assumes any legal liability or responsibility for the accuracy, completeness, or usefulness of any information, apparatus, product, or process disclosed, or represents that its use would not infringe privately owned rights. Reference herein to any specific commercial product, process, or service by trade name, trademark, manufacturer, or otherwise does not necessarily constitute or imply its endorsement, recommendation, or favoring by the United States government or any agency thereof. The views and opinions of authors expressed herein do not necessarily state or reflect those of the United States government or any agency thereof.

Available electronically at http://www.osti.gov/bridge

Available for a processing fee to U.S. Department of Energy and its contractors, in paper, from:

U.S. Department of Energy

Office of Scientific and Technical Information

P.O. Box 62

Oak Ridge, TN 37831-0062

phone: 865.576 .8401

fax: 865.576 .5728

email: mailto:reports@adonis.osti.gov

Available for sale to the public, in paper, from:

U.S. Department of Commerce

National Technical Information Service

5285 Port Royal Road

Springfield, VA 22161

phone: 800.553.6847

fax: 703.605.6900

email: orders@ntis.fedworld.gov

online ordering: http://www.ntis.gov/ordering.htm 


\title{
Using Economics to Determine the Efficient Curtailment of Wind Energy
}

\begin{abstract}
This paper discusses the potential societal benefits to the energy market by allowing the dispatch of wind generation in times when it may enhance reliability and be economically advantageous to do so. Because wind is so new to the power system and many system operators consider the resource a resource difficult to schedule, most markets force wind to offer its energy as a price taker. That is, regardless of what the price is, wind will supply all the energy it can and will settle on whatever price the market dictates. Wind is a variable resource and more effort is continuing in the industry on being able to forecast the output of these resources to be used in market and system operations.
\end{abstract}

Many markets, especially those in the United States, are evolving into ones that settle on bus-bar or nodal pricing. That is, for every generator bus on the transmission network, there is a separate market price (locational marginal price or LMP) usually consisting of energy cost, transmission loss cost, and transmission congestion cost components. Lastly, because wind generation has been evolving at such a rapid rate - much faster than that of transmission infrastructure - issues with transmission congestion can cause some or all of the power injected from a wind plant bus to be valueless to the market. This leads to negative locational prices and wind suppliers who pay for every MWh of energy that is produced rather than receive payment for that energy. This paper discusses these issues and possible solutions for wind and use of economic dispatch based on energy prices.

\section{Background}

Wind power in the United States and around the world is experiencing a very rapid growth period. Wind power as free fuel and as emissions-free output is a very attractive alternative to volatile fossil fuel prices in a warming global environment. However, there are certain issues with wind that must be considered when interconnecting more and more of it onto the power system. The two main issues are its variability and unpredictability. The variability of wind is described by the nature of its fuel source, the wind. The speed of wind is constantly changing throughout different regions, different local areas, different times of day, and different seasons. This changing wind speed causes variation in the power output or power potential of a wind turbine that effectively causes variation of the entire wind plant. The unpredictability describes the inability to accurately predict the output or potential of a wind plant, which raises the possibility of discrepancies in the generation-load balance that must be maintained. A combination of these issues has led power system control-area operators to treat wind most closely to that of fixed load because it has no elasticity with price and must accept the market price of energy regardless of what it may be. Since wind does have approximately zero variable cost, this is usually not considered a large issue to wind plant owners and has brought little attention since wind first started participating in the electricity market. 
A second issue of wind power integration is that of transmission service. Wind power is usually located in wind-rich areas, and usually not in close proximity to load centers or existing transmission facilities. The average construction of transmission facilities takes several years more than the average construction and completion of a wind plant project. This means that transmission may not be available by the time the wind project is operational and either the wind project is delayed or alternative transmission with much less available capacity must be used. Also, since wind power is seldom operating at its full operating capacity, when transmission is built for the additional power needed from wind, it may be more economic to build transmission capacity that is lower than the total nameplate capacity of the plant. Since the wind does, on occasion, operate at or near its operating capacity, depending on what other resources are operating and sharing any available transmission capacity, it is not infrequent for these transmission lines to be loaded at or exceeding their full capacity. If exceeded, this means that something needs to be curtailed and other units redispatched to relieve the congestion. Most often, it is beneficial from a market standpoint to curtail or dispatch down the fossil generation since it is the most costly resource. However, with more and more wind power being added to the system, it may be necessary for other options.

\section{Negative Market Prices}

In certain transmission congestion circumstances, it is possible that power injected at a bus is doing more harm than good to the system. This can be explained in more detail by the following; the locational marginal price (LMP) is usually defined as the marginal cost to serve one more megawatt (MW) of load at a certain location. When the generator at a specific location is causing economic harm to the entire system, adding one more MW of load may have somewhat counterintuitive effects. In other words, although usually adding an additional MW of load would typically increase costs because extra power from a generator is needed, analysis of the system may show that increasing the load (or decreasing the generation) will result in a total savings to the system based on the dispatch of all resources. Now let's examine an example of two fossil-fuel generators on a 3-bus system where one bus has a load obligation.

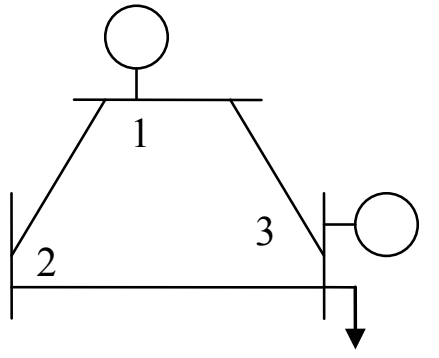

\begin{tabular}{|l|}
\hline $\mathrm{G} 1: 250 \mathrm{MW}$ \\
$10 \$ / \mathrm{MWh}$ \\
$\mathrm{G} 3: 100 \mathrm{MW}$ \\
50 \$/MWh \\
\hline
\end{tabular}

$\mathrm{L} 3: 150 \mathrm{MW}$
$\mathrm{X} 12=\mathrm{X} 13=\mathrm{X} 23$

Figure 1 - A 3-bus, 3-line power network. 
Figure 1 is a 3-bus, 3 -line power network with generators at busses 1 and 3, a load at bus 3 , and three equal line impedances. Looking at the generation cost and capacity numbers on this 3 bus system without line loading limits, it is obvious that Generator 1 (G1) would supply all $150 \mathrm{MW}$ of load in this instance and Generator 3 (G3) would not be needed. Now, look at the same example with a transmission limit of $33 \mathrm{MW}$ on the 2-3 branch.
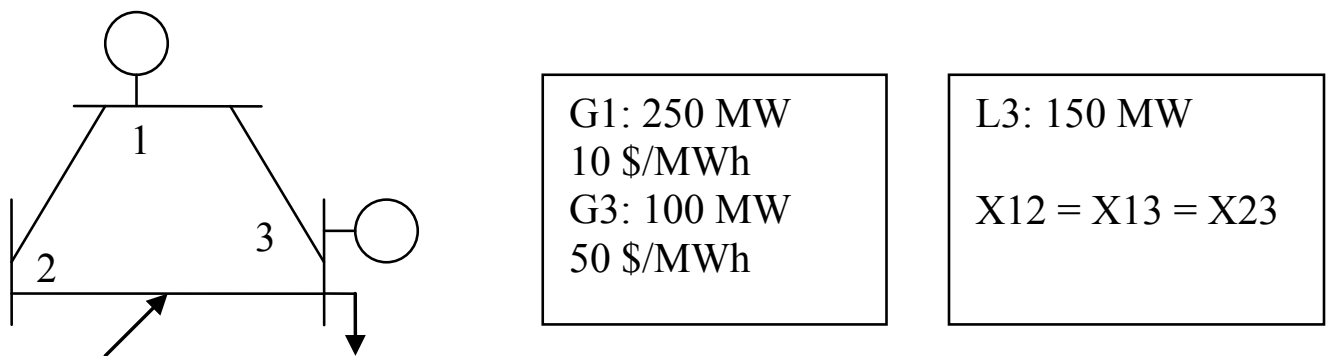

33 MW limit

Figure 2 - A 3-bus, 3-line power network with transmission limit.

In Figure 2, if G1 provided the entire load, then the transmission limit would be exceeded. The system would need to be redispatched in order to provide the lowest cost to the system while still obeying all constraints. The resulting generator output and branch line loadings are shown below:

G1: $100 \mathrm{MW}$

G3: $50 \mathrm{MW}$

1-2 branch: $33 \mathrm{MW}$
2-3 branch: $33 \mathrm{MW}$

1-3 branch: $67 \mathrm{MW}$

Now let's look at the resulting LMPs from this scenario. A good way to estimate an LMP is to add one MW of load to the particular bus in question and calculate the incremental costs to serve this one MW added to the total load. By adding one MW of load to bus 1, this can easily be supplied by G1 since this does not change any power injections on the transmission network. By adding one MW of load to bus 3, this power must be supplied by G3 since the transmission system is congested and no more power is available from G1. If one more MW of load is added at bus 2, this changes the system a bit. Since the transmission line that is congested is on the 2-3 branch, G1 can actually supply the load at bus 2 and still not violate the transmission limit. In fact, since power will be distributed in both directions around the loop to get to bus 2 , it actually will produce counter-flow and relieve some of the congestion on the 2-3 branch. This allows G1 to supply an additional MW of power on top of what it is supplying to the load at bus 2 and that can now supply the load at bus 3. Now, one less MW is needed from G3. Table 1 (next page) shows the 3 results of this approximation and the resultant LMPs. 
Table 1 - Approximation results and the resulting LMPs.

\begin{tabular}{|l|l|l|l|l|l|l|l|l|l|l|}
\hline & $\begin{array}{l}\text { Gen 1 } \\
\text { MW }\end{array}$ & & $\begin{array}{l}\text { Gen 1 } \\
\text { Cost }\end{array}$ & $\begin{array}{l}\text { Gen 3 } \\
\text { MW }\end{array}$ & $\begin{array}{l}\text { Gen 3 } \\
\text { Cost }\end{array}$ & $\begin{array}{l}\text { Total } \\
\text { MWh }\end{array}$ & $\begin{array}{l}\text { How much } \\
\text { more? }\end{array}$ \\
\hline Base Case & 100 & $*$ & 50 & $*$ & $\begin{array}{l}\$ 50 / \\
\text { MWh }\end{array}$ & $=$ & $\$ 3500$ & \\
\hline $\begin{array}{l}\text { Add 1 } \\
\text { MW to } \\
\text { Bus 1 }\end{array}$ & 101 & $*$ & $\begin{array}{l}\$ 10 / \\
\text { MWh }\end{array}$ & + & 50 & $*$ & $\begin{array}{l}\$ 50 / \\
\text { MWh }\end{array}$ & $=$ & $\$ 3510$ & $\$ 10$ \\
\hline $\begin{array}{l}\text { Add 1 } \\
\text { MW to } \\
\text { Bus 3 }\end{array}$ & 100 & $*$ & $\begin{array}{l}\$ 10 / \\
\text { MWh }\end{array}$ & + & 51 & $*$ & $\begin{array}{l}\$ 50 / \\
\text { MWh }\end{array}$ & $=$ & $\$ 3550$ & $\$ 50$ \\
\hline $\begin{array}{l}\text { Add 1 } \\
\text { MW to } \\
\text { Bus 2 }\end{array}$ & 102 & $*$ & $\begin{array}{l}\$ 10 / \\
\mathrm{MWh}\end{array}$ & + & 49 & $*$ & $\begin{array}{l}\$ 50 / \\
\mathrm{MWh}\end{array}$ & $=$ & $\$ 3470$ & $\$-30$ \\
\hline
\end{tabular}

The "How much more?" column shows the LMPs. Note that increasing the load at bus 2 will actually lessen the total production costs, thus, giving the negative LMP.

Now let's examine the same example, increase the transmission line limit for branch 2-3 to $100 \mathrm{MW}$ and the load at bus 3 to $250 \mathrm{MW}$. We add a wind plant at bus 2 currently operating or predicted to operate at $100 \mathrm{MW}$. In this example, we assume the market requires the wind generator to bid in the market as a price taker.

Assuming the wind generator's cost is $\$ 0 / \mathrm{MWh}$, this produces an identical result to the prior example (see Table 2 below).

Table 2 - Approximation results with addition of wind generator and the resulting LMPs.

\begin{tabular}{|l|l|l|l|l|l|l|l|l|l|l|l|}
\hline & $\begin{array}{l}\text { Wind } \\
\text { Gen MW }\end{array}$ & $\begin{array}{l}\text { Gen 1 } \\
\text { MW }\end{array}$ & $\begin{array}{l}\text { Gen 1 } \\
\text { Cost }\end{array}$ & $\begin{array}{l}\text { Gen 3 } \\
\text { MW }\end{array}$ & $\begin{array}{l}\text { Gen 3 } \\
\text { Cost }\end{array}$ & Total & $\begin{array}{l}\text { How much } \\
\text { more? }\end{array}$ \\
\hline $\begin{array}{l}\text { Base } \\
\text { Case }\end{array}$ & 100 & 100 & $*$ & $\begin{array}{l}\$ 10 / \\
\text { MWh }\end{array}$ & + & 50 & $*$ & $\begin{array}{l}\$ 50 / \\
\mathrm{MWh}\end{array}$ & $=$ & $\$ 3500$ & \\
\hline $\begin{array}{l}\text { Add 1 } \\
\text { MW to } \\
\text { Bus 1 }\end{array}$ & 100 & 101 & $*$ & $\begin{array}{l}\$ 10 / \\
\mathrm{MWh}\end{array}$ & + & 50 & $*$ & $\begin{array}{l}\$ 50 / \\
\mathrm{MWh}\end{array}$ & $=$ & $\$ 3510$ & $\$ 10$ \\
\hline $\begin{array}{l}\text { Add 1 } \\
\text { MW to } \\
\text { Bus 3 }\end{array}$ & 100 & 100 & $*$ & $\begin{array}{l}\$ 10 / \\
\mathrm{MWh}\end{array}$ & + & 51 & $*$ & $\$ 50 /$ & $=$ & $\$ 3550$ & $\$ 50$ \\
\hline $\begin{array}{l}\text { Add 1 } \\
\text { MW to } \\
\text { Bus 2 }\end{array}$ & 100 & 102 & $*$ & $\begin{array}{l}\$ 10 / \\
\mathrm{MWh}\end{array}$ & + & 49 & $*$ & $\begin{array}{l}\$ 50 / \\
\mathrm{MWh}\end{array}$ & $=$ & $\$ 3470$ & $\$-30$ \\
\hline
\end{tabular}

In many of the U.S. markets, generators and loads settle on what is called a twosettlement system. That is, they will settle on purely financial terms what is usually referred to as a day-ahead market, and will make up any differences that occur from the original prediction in what is referred to as a real-time market or balancing market. These 
types of negative prices are usually more prevalent in real-time markets. The reason for this is that there can be more unanticipated results that happen in real-time and not enough of a time horizon to make the most economic adjustments. Real-time markets usually can only dispatch units that have already been committed and because of generator ramping rates there is usually much less power that can be dispatched in this market. This is sometimes more harmful to wind generators than other generators because of the variable and uncertain nature of wind.

Uncertainties involved in bidding in the market for wind generation can make it economically harmful to bid in the day-ahead market, so many choose not to and will settle solely on real-time prices. For example, if they sell in the day-ahead market and do not meet their day-ahead schedule, they must buy back the power in the real-time market. Wind generators may try to sell a small amount of power in the day-ahead market and similarly, will sell the rest of what they produce in the real-time market at real-time prices. Therefore, whether they are selling into the day-ahead market or not, they are much more affected by real-time prices due to the uncertainty characteristics.

Lastly, because they are considered as price takers, they are constrained from the market perspective in both upward and downward directions. This results in one less unit that can be used in redispatch efforts when a constraint is observed.

\section{Negative Market Prices in the Real World}

These pricing issues are becoming more of an actual problem than just a theoretical problem, given the large addition of wind power that has occurred in the past few years. In the Electric Reliability Council of Texas (ERCOT), for example, the western zone, which has the majority of the wind in the region, had negative prices for more than $20 \%$ of all hours in the month of April 2008. The average negative price was between $\$ 40$ and $\$ 30$ per MWh. This occurred even without ERCOT having implemented a nodal market. ${ }^{1}$ This means that it is possible that once ERCOT moves to a nodal market, certain wind generator buses may have more of an impact on the zonal interface transmission congestion than is seen today, and may have further consequences on its individual nodal price. It is unclear today as to what market constraints are apparent in the ERCOT market (i.e., if the wind generators are forced to bid as price takers). It is likely due to their values that these prices are in fact being set by wind generators. However, the full response of the wind generators acting on the prices is unclear. Since generators do not individually bid into the market, it is unclear whether the wind power generators are actually the ones responding to these negative prices in order to relieve congestion. ${ }^{2}$

\footnotetext{
${ }^{1}$ ERCOT currently settles on zonal prices. Zonal prices use interface limits between different regions in the control area. This may hide specific congested lines and specific generators that are contributing most to congestion.

${ }^{2}$ In the ERCOT market, Qualified Scheduling Entities will submit a plan for a portfolio for a number of both generation and load to ERCOT in advance of the market close.
} 
In other markets, where nodal pricing is available but wind generation may not be as substantial of a resource, there are significant occurrences of negative prices as well. In the NY Independent System Operator (NYISO), one wind generator bus experienced negative prices more than $20 \%$ of the hours in May 2008. Of these $20 \%$, close to half are below the current production tax credit (PTC) value - a major revenue stream for wind generation. This could mean, depending on what state environmental revenues are available, that the wind generator lost money to generate during $10 \%$ of all intervals. The average price below the PTC was \$-149 per MWh. To go a bit further, had all negative prices been eliminated in this month, the average LMP of the month would have changed from $\$ 39$ to $\$ 66$, which corresponds to an approximate revenue change of $\$ 27,000$ per average monthly MW to over $\$ 42,000$ per average monthly MW, or over a $50 \%$ increase in revenue.

A related issue is the validity of wind resources selling to a market pool versus the notion of them having fixed bilateral contracts with load serving entities that are less impacted from variable market prices. In the short term, market tariffs have some way of defining transmission charges when congestion costs are incurred. That is, even when a bilateral agreement for energy is stated, when the prices due to congestion or losses between the seller and buyer differ, the owner of the bilateral agreement has to pay the difference. This is usually, but not always, the load or utility that is purchasing the power from the wind supplier. So in this case, it may be the load that is the one that is being directly harmed rather than the wind.

However, when thinking in terms of the long term, the key idea to understand is that if all environmental benefits were put aside and the market value of wind was considered as it is with any other type of generation, why would a load continue to purchase power from a location where it may continue to pay these large transmission usage charges? Prices agreed upon in a bilateral agreement should largely reflect those that are set in the market in the long-term. David Patton, ERCOT's Independent Market Advisor, said something to this effect in his 2006 ERCOT State of the Market Report.

"Although most power is purchased through forward contracts of varying duration, the spot prices emerging from the balancing energy market should directly affect forward contract prices." 3

\section{Further Issues}

The financial complications that are caused by lack of transmission and dispatch capability are sufficient enough an issue for independent system operators (ISOs) and regional transmission operators (RTOs) (the entities that operate regional grids and wholesale energy markets) to look at mitigation techniques to prevent this situation from

\footnotetext{
3 "ERCOT 2006 State of the Market Report", Potomac Economics, August 2007. http://www.potomaceconomics.com/uploads/ercot_reports/2006\%20ERCOT\%20SOM\%20REPORT_Final . pdf
} 
occurring. There are also additional issues that can occur to more than just the settling parties, including those of reliability. With a large negative price, where a wind generator is selling into the market and having to pay more amounts of money than can be gained from any other type of incentive, there are usually a few possible scenarios. The wind generator can continue to generate and lose money from the negative-valued production of energy. Or the wind generator may decide that it cannot afford to continue to inject energy and turn the entire plant off. In the example similar to that described in Table 2, there are usually no reliability issues with the wind generator continuing to run. The transmission limit is not exceeded because the system operator has scheduled the system around the wind generator's constrained output. The negative LMP value comes from the reduction in output of cheap generation somewhere on the system, and to account for that loss of generation, the addition of very expensive units elsewhere.

Because of the small impact, or generation shift factor, that a generator may have on the congested line, it may need to adjust a large amount of the generator's power to reduce 1 MW of congestion on the line. This multiplies the price impact on the line. However, the line limit is not exceeded, and the generation and load on the system is balanced. If the plant was a 200 to $300-\mathrm{MW}$ plant, and it took itself offline to avoid negative prices, the system has just lost 200 to $300 \mathrm{MW}$, causing a potentially significant reliability issue. Possibly, the wind generator need only reduce output by $10 \mathrm{MW}$ to relieve the congested line. In this case, a partial reduction in output of wind power would seem to be the appropriate response.

Another possible issue is the efficiency of the market that the system operator is running. If prices were set based on the wind generator staying steady, and its power is manually reduced, this diverges prices from what the market actually did. To have the most efficient market, the economic dispatch program should best predict the outputs of generation for the best reflection on the marginal cost or price of energy. LMPs or energy prices in general are almost always related to the economic dispatch by the bids that the generators provide. If the LMP is below the bid cost of the generator, the generator should be ramped down or turned off. If the LMP is above the generator's bid cost, the generator should either be ramped up or operated at its upper limit. Because most markets require wind generators to bid as pure price takers, their artificial bid cost is essentially negative infinite. ${ }^{4}$ Since bid costs are supposed to reflect the actual variable cost of a resource, this is obviously not an accurate reflection.

\section{Resolution}

A possible resolution to some of the inefficiencies described in this paper is to allow wind generators to provide economic offers the same way that other generators do. The wind generator should use an energy forecast as its upper potential or capacity and $0 \mathrm{MW}$ as its minimum operating level. The wind generator then should provide the market operator with a bid cost that shows their economic willingness to generate. An example

\footnotetext{
${ }^{4}$ Some markets may have penalty factors in place that will allow curtailment of self-schedules or "price takers" below some very negative number.
} 
might be 0 dollars, however, because of certain incentives that wind generators get from national or state governments for generating (e.g., production tax credit) they may choose to provide a negative value as their bid cost. The purpose would be that the wind generator should never be scheduled if the price is below the bid cost that is given. If two wind generators are behind a constrained transmission line, one with a bid of $\$ 0$ and the other with a bid of $\$-15$, the one with the $\$ 0$ bid would most likely be backed down before the one with the $\$-15$ bid. The key difference of this idea is that unlike other generating resources, the wind's total potential or upper limit will be changing typically every market interval. If this were to be done the market solution - economic dispatch or unit commitment program - will determine when it is appropriate to curtail the wind and at exactly which level it will curtail it to. We will now use the example shown before and give the wind generator a bid cost of $\$ 0$ and allow the market to dispatch the wind as a normal resource. Table 3 shows the outputs of all generators in the case without economic curtailment and the case with economic curtailment. Tables 4 and 5 show the resulting price information without curtailment and with curtailment, respectively.

Table 3 - Generation Output With and Without Using Economic Wind Curtailment

\begin{tabular}{|l|l|l|}
\hline & $\begin{array}{l}\text { Without economic } \\
\text { curtailment }\end{array}$ & $\begin{array}{l}\text { With economic } \\
\text { curtailment }\end{array}$ \\
\hline Generator 1 & $100 \mathrm{MW}$ & $200 \mathrm{MW}$ \\
\hline Generator 2 (wind) & $100 \mathrm{MW}$ & $50 \mathrm{MW}$ \\
\hline Generator 3 & $50 \mathrm{MW}$ & $0 \mathrm{MW}$ \\
\hline
\end{tabular}

Tables of Production Costs and LMPs

Table 4 - Costs and Prices without Economic Curtailment

\begin{tabular}{|l|l|l|l|l|l|l|l|l|l|l|l|}
\hline & $\begin{array}{l}\text { Wind } \\
\text { Gen } \\
\text { MW }\end{array}$ & $\begin{array}{l}\text { Gen 1 } \\
\text { MW }\end{array}$ & $\begin{array}{l}\text { Gen 1 } \\
\text { Cost }\end{array}$ & $\begin{array}{l}\text { Gen 3 } \\
\text { MW }\end{array}$ & $\begin{array}{l}\text { Gen 3 } \\
\text { Cost }\end{array}$ & Total & $\begin{array}{l}\text { How } \\
\text { much } \\
\text { more? }\end{array}$ \\
\hline $\begin{array}{l}\text { Base } \\
\text { Case }\end{array}$ & 100 & 100 & $*$ & $\begin{array}{l}\$ 10 / \\
\text { MWh }\end{array}$ & + & 50 & $*$ & $\begin{array}{l}\$ 50 / \\
\mathrm{MWh}\end{array}$ & $=$ & $\$ 3500$ & \\
\hline $\begin{array}{l}\text { Add 1 } \\
\text { MW to } \\
\text { Bus 1 }\end{array}$ & 100 & 101 & $*$ & $\begin{array}{l}\$ 10 / \\
\mathrm{MWh}\end{array}$ & + & 50 & $*$ & $\begin{array}{l}\$ 50 / \\
\mathrm{MWh}\end{array}$ & $=$ & $\$ 3510$ & $\$ 10$ \\
\hline $\begin{array}{l}\text { Add 1 } \\
\text { MW to } \\
\text { Bus 3 }\end{array}$ & 100 & 100 & $*$ & $\begin{array}{l}\$ 10 / \\
\mathrm{MWh}\end{array}$ & + & 51 & $*$ & $\begin{array}{l}\$ 50 / \\
\mathrm{MWh}\end{array}$ & $=$ & $\$ 3550$ & $\$ 50$ \\
\hline $\begin{array}{l}\text { Add 1 } \\
\text { MW to } \\
\text { Bus 2 }\end{array}$ & 100 & 102 & $*$ & $\begin{array}{l}\$ 10 / \\
\mathrm{MWh}\end{array}$ & + & 49 & $*$ & $\begin{array}{l}\$ 50 / \\
\mathrm{MWh}\end{array}$ & $=$ & $\$ 3470$ & $\$-30$ \\
\hline
\end{tabular}


Table 5 - Costs and Prices with Economic Curtailment

\begin{tabular}{|l|l|l|l|l|l|l|l|l|l|l|l|}
\hline & $\begin{array}{l}\text { Wind } \\
\text { Gen } \\
\text { MW }\end{array}$ & $\begin{array}{l}\text { Gen 1 } \\
\text { MW }\end{array}$ & $\begin{array}{l}\text { Gen 1 } \\
\text { Cost }\end{array}$ & $\begin{array}{l}\text { Gen 3 } \\
\text { MW }\end{array}$ & $\begin{array}{l}\text { Gen 3 } \\
\text { Cost }\end{array}$ & Total & $\begin{array}{l}\text { How } \\
\text { much } \\
\text { more? }\end{array}$ \\
\hline $\begin{array}{l}\text { Base } \\
\text { Case }\end{array}$ & 50 & 200 & $*$ & $\begin{array}{l}\$ 10 / \\
\text { MWh }\end{array}$ & + & 0 & $*$ & $\begin{array}{l}\$ 50 / \\
\text { MWh }\end{array}$ & $=$ & $\$ 2000$ & \\
\hline $\begin{array}{l}\text { Add 1 } \\
\text { MW to } \\
\text { Bus 1 }\end{array}$ & 50 & 201 & $*$ & $\begin{array}{l}\$ 10 / \\
\text { MWh }\end{array}$ & + & 0 & $*$ & $\begin{array}{l}\$ 5 / \\
\text { MWh }\end{array}$ & $=$ & $\$ 2010$ & $\$ 10$ \\
\hline $\begin{array}{l}\text { Add 1 } \\
\text { MW to } \\
\text { Bus 3 }\end{array}$ & 49 & 202 & $*$ & $\begin{array}{l}\$ 10 / \\
\text { MWh }\end{array}$ & + & 0 & $*$ & $\$ 50 /$ & $=$ & $\$ 2020$ & $\$ 20$ \\
\hline $\begin{array}{l}\text { Add 1 } \\
\text { MW to } \\
\text { Bus 2 }\end{array}$ & 51 & 200 & $*$ & $\begin{array}{l}\$ 10 / \\
\mathrm{MWh}\end{array}$ & + & 0 & $*$ & $\begin{array}{l}\$ 50 / \\
\mathrm{MWh}\end{array}$ & $=$ & $\$ 2000$ & $\$ 0$ \\
\hline
\end{tabular}

Table 5 shows that the system came up with a much more cost effective solution. Three things happened in this new solution. The total production costs were substantially lowered, the price that the load at bus 3 pays has been substantially lowered, and the price that the wind generator gets paid is no longer financially harmful. Also, there were no negative impacts to any party. G3 is no longer generating, but in the original solution (Table 4), it was not making any profit, so the profit margin has not changed.

Because of the transmission distribution effects, it is more economic to curtail the wind generator than to curtail G1. If the price were still largely negative, then the wind generator should have been scheduled all the way to zero. Theoretically, the only time any generator should be affected by negative pricing is due to a physical constraint of the generator. This may include minimum operating limits, minimum run times, ramp rates, etc. Most modern wind plants do not have these types of physical constraints and, therefore, should not be blocked by an artificial market constraint. In the situation shown above (Table 5), if the wind generator follows the directions given, the system is balanced, the line is not overloaded, and the operators did not have to make any calls or decisions. Costs are reduced and prices match what actually occurred.

A list of further benefits from this approach is detailed below:

- Better efficiency of the market; least-cost energy solution to consumers

- Convergence of day-ahead to real-time pricing

- Convergence of physical results to pricing results

- Less strain on operators to make curtail calls (i.e., scheduling software does it for them)

- Less financial harm to wind generators

- Possibly less financial harm to other generators who have true physical constraints

- Reliability benefits; balancing area-directed curtailment vs. self-directed curtailment 
- Reliability benefits; better management of otherwise unmanageable congestion

- Wind competition: In places where the entire load can be served by wind, this can determine what plants to curtail

- Same methodology described in this paper with transmission congestion can essentially be used for large ramp events and minimum-load periods

\section{Ongoing Issues}

The first and most important issue in making these improvements is ensuring that when wind generators are getting signals to limit their output, they are following these directions. These market mechanisms only incentivize solving reliability problems, and without the wind plants following directions, there is no real benefit. It should be up to the ISO to determine what best ways are used in incentivizing behavior of other resources to follow directions, and how those may apply to wind in this situation. In some instances, this may result in the need for financial penalties to wind generators not following directions during these conditions.

With more and more wind power entering the system, and transmission capacity lagging behind, this may cause an issue on the amount of wind capacity being built compared to RPS goals issued by states. Another issue in need of more research is how this impacts wind generation forecasts being produced for the plants. Statistically based forecasts will usually use the correlation of wind speed along with wind power to determine applicable power curves of the plant. The more often a wind generator is producing at less than potential, the more this relationship becomes skewed. Lastly, if it were the plan for this communication process to be fully automated from control center to generator, as is other generation, there may need to be additional infrastructure built to feed curtailment signals to the plant. If the plant ignores any sort of base point coming from a system operator $99 \%$ of the time, how will it know when it needs to follow the base point during the $1 \%$ of the time this situation occurs?

It is also important to note that different ISOs will have different market structures, bidding structures, and settlement structures, so that this procedure would have to be assessed in specific ways for specific regions. Some of the key differences that may affect the application of this operation are listed below:

- Ex Ante vs. Ex Post pricing (i.e., prices set based on schedules or on actual outcomes)

- Zonal vs. nodal pricing

- Individual supplier offers vs. scheduling entities who offer a portfolio of suppliers

- Systems with more aggregation of wind plants vs. concentrated layout

- Negative price allowance

- Two settlement vs. single settlement

- Market dominated by bilateral power purchase agreements vs. selling directly to market pool 
- Vertically integrated utilities in footprint vs. fully divested utilities

- Differences in transmission capacity, and resource and flexibility mix may present different needs

- Regulated utilities may also be able to use something to this effect in their economic dispatch programs over their footprint

\section{Conclusion}

The amount of wind power being added into many power systems is increasing dramatically. This increase requires a similar increase in the amount of transmission capacity to be able to supply many loads with low-cost energy. When transmission is not yet built and constraints on the transmission network are apparent, fossil generation should be dispatched down in order to save costs and fuel. However, when economically advantageous to do so, wind power should be allowed to be on dispatch to relieve transmission congestion constraints. Constraints set forth in the market should be based on physical constraints alone. Allowing wind generation to provide economic offers in the electricity market promotes increased market efficiency as well as enhanced reliability and large savings to all market participants.

\section{References}

The Electric Reliability Council of Texas (ERCOT) at: http://www.ercot.com/

The New York Independent System Operator (NYISO) at:

http://www.nyiso.com/public/index.jsp

Many of the solutions in this paper were verified using GAMS and solved using the CPLEX solver.

GAMS Development Corporation, "GAMS: The Solver Manuals," Washington, DC, 2005. 


\section{REPORT DOCUMENTATION PAGE}

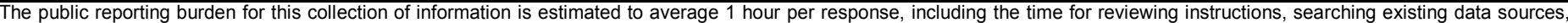

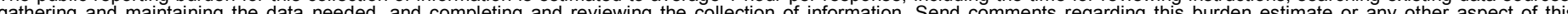

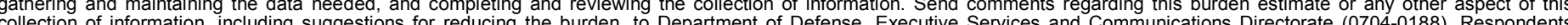

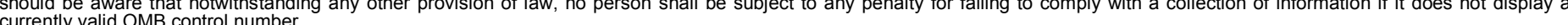

PLEASE DO NOT RETURN YOUR FORM TO THE ABOVE ORGANIZATION.

\begin{tabular}{l|l|l|l} 
1. REPORT DATE (DD-MM-YYYY) & 2. REPORT TYPE & 3. DATES COVERED (FrOm - TO)
\end{tabular}

February 2009

Technical Report

4. TITLE AND SUBTITLE

Using Economics to Determine the Efficient Curtailment of Wind Energy 5a. CONTRACT NUMBER

DE-AC36-08-GO28308

5b. GRANT NUMBER

5c. PROGRAM ELEMENT NUMBER

5d. PROJECT NUMBER

NREL/TP-550-45071

5e. TASK NUMBER

WER95501

5f. WORK UNIT NUMBER
7. PERFORMING ORGANIZATION NAME(S) AND ADDRESS(ES)

National Renewable Energy Laboratory

1617 Cole Blvd.

Golden, CO 80401-3393
8. PERFORMING ORGANIZATION REPORT NUMBER

NREL/TP-550-45071

9. SPONSORING/MONITORING AGENCY NAME(S) AND ADDRESS(ES)

10. SPONSOR/MONITOR'S ACRONYM(S) NREL

11. SPONSORING/MONITORING AGENCY REPORT NUMBER

12. DISTRIBUTION AVAILABILITY STATEMENT

National Technical Information Service

U.S. Department of Commerce

5285 Port Royal Road

Springfield, VA 22161

13. SUPPLEMENTARY NOTES

14. ABSTRACT (Maximum 200 Words)

This paper discusses the potential societal benefits to the energy market by allowing the dispatch of wind generation

in times when it may enhance reliability and be economically advantageous to do so.

15. SUBJECT TERMS

wind power; wind energy; curtailment; economics; grid; integration; system integration; utilities; system operation

\begin{tabular}{|c|c|c|c|}
\hline \multicolumn{2}{|c|}{$\begin{array}{l}\text { 16. SECURITY } \\
\text { CLASSIFICATION OF: }\end{array}$} & \multicolumn{2}{|c|}{$\begin{array}{c}\text { 17. LIMITATION OF ABSTRACT } \\
\text { UL }\end{array}$} \\
\hline $\begin{array}{l}\text { a. REPORT } \\
\text { Unclassified }\end{array}$ & $\begin{array}{l}\text { b. ABSTRACT } \\
\text { Unclassified }\end{array}$ & $\begin{array}{l}\text { c. THIS PAGE } \\
\text { Unclassified }\end{array}$ & \\
\hline
\end{tabular}

\begin{tabular}{|l|l|}
$\begin{array}{l}\text { 18. NUMBER } \\
\text { OF PAGES }\end{array}$ & 19a. NAME OF RESPONSIBLE PERSON \\
& 19b. TELEPHONE NUMBER (Include area code) \\
&
\end{tabular}

